\title{
Lamina propria mast cells in biopsies from children with Crohn's disease
}

\author{
IR SANDERSON,*KBP LEUNG, †FL PEARCE,† JA WALKER-SMITH* \\ From the *Laboratory for Paediatric Gastroenterology, St Bartholomew's Hospital, London, and the \\ $\dagger$ Department of Chemistry, University College, London
}

SUMMARY Biopsies from actively inflamed areas of terminal ileum or colon in children with Crohn's disease were examined both for lamina propria mast cell density and histamine content. These were reduced in comparison with those of normal controls. The release of histamine from biopsies of inflamed tissue did not differ greatly from that of normal tissue, either spontaneously or after receiving an antihuman $\operatorname{IgE}$ challenge.

The role of lamina propria mast cells in Crohn's disease has not been established. Investigations into mast cell densities, using light microscopy, have given conflicting results. Hiatt and $\mathrm{Katz}^{1}$ claimed that the density of mast cells was increased in Crohn's disease, whereas Lloyd et $a l^{2}$ suggested that it was reduced. Thompson and Buchmann ${ }^{3}$ thought there was no important change. These studies, however, were done before it was widely recognised that mucosal mast cells were unstable in buffered formol saline ${ }^{4}$ and the experiments need to be repeated in tissue preserved in a more suitable fixative. Electron microscopy, although effective for identifying individual mast cells and assessing their state of degranulation, ${ }^{5}$ is an unsatisfactory technique for quantifying mast cells over a large area of lamina propria.

Histamine is stored in mast cells. The histamine content of whole biopsies could, therefore, be expected to reflect mast cell density, provided that the cells are not degranulated. Histamine release, both spontaneously and in the presence of anti-IgE, has been used to assess the degree of $\mathrm{IgE}$ binding to mast cells in lung tissue both in resected specimens ${ }^{6}$ and in bronchoalveolar lavage. ${ }^{7}$ It is not known whether IgE is bound to mast cells in the gut either in normal patients or in those with Crohn's disease.

The aim of this paper was to assess the density of mast cells in the lamina propria in Crohn's disease in appropriately fixed tissue, using light microscopy and to measure the histamine content of whole biopsies. The ability of mast cells to release histamine spontaneously and in the presence of anti-IgE was also investigated.

Accepted for publication 29 October 1985

\section{Patients and methods}

Fourteen children with active Crohn's disease attending the paediatric inflammatory bowel disease clinic at St Bartholomew's Hospital (Table) were admitted for colonoscopy and ileoscopy. The diagnosis was made on clinical features, erythrocyte sedimentation rate, $\mathrm{C}$ reactive protein and radiology, ${ }^{8}$ as well as characteristic histology. ${ }^{9}$ Biopsies from eight children showed non-caseating granulomas. A disease activity index was determined by the method of Lloyd-Still and Green ${ }^{10}$ whereby a maximum of 100 points is obtained by a completely normal child. Eight of the children were new cases.

Twelve children (aged 8-15 years) presenting with recurrent abdominal pain, but in whom no evidence of hitherto recognised gastrointestinal disease was found, served as normal controls. Eight children with active ulcerative colitis acted as diseased controls.

\section{BIOPSIES}

Biopsies from areas of active inflammation in children with Crohn's disease were fixed in buffered formol saline and stained with haematoxylin and eosin for diagnostic histology; biopsies of adjacent areas were fixed in Carnoy's fluid for mast cell staining. Further biopsies from the same site were placed in physiological saline for histamine assays. All biopsies were taken from the same site under direct vision at endoscopy to reduce potential inaccuracies caused by variability in the intensity of the inflammatory response in the mucosa in Crohn's disease. Histamine was not assayed in biopsies from children with ulcerative colitis. Biopsies were also taken each time for electron microscopy to check that mast cells were not severely degranulated. 
Table Clinical features and treatment of children with active Crohn's disease

\begin{tabular}{|c|c|c|c|c|c|}
\hline Case name & Age & Sex & Treatment & Affected area & Activity index \\
\hline LD & 8 & $\mathbf{F}$ & nil & Terminal ileum & 77 \\
\hline MB & 10 & $\mathbf{F}$ & nil & Terminal ileum, colon & 54 \\
\hline SC & 10 & $\mathrm{M}$ & $\begin{array}{l}\text { sulphasalazine } \\
\text { prednisolone }(10 \mathrm{mg} / \mathrm{day})\end{array}$ & Colon & 81 \\
\hline MB & 10 & $\mathbf{M}$ & nil & Terminal ileum, colon & 64 \\
\hline AN & 11 & $\mathbf{F}$ & nil & Terminal ileum & 58 \\
\hline NHP & 12 & $\mathbf{F}$ & $\begin{array}{l}\text { sulphasalazine } \\
\text { prednisolone }(15 \mathrm{mg} / \mathrm{day})\end{array}$ & Colon & 67 \\
\hline MD & 12 & $\mathbf{F}$ & $\begin{array}{l}\text { sulphasalazine } \\
\text { prednisolone }(10 \mathrm{mg} / \text { day })\end{array}$ & Terminal ileum & 63 \\
\hline MD & 12 & $\mathbf{M}$ & nil & Terminal ileum & 72 \\
\hline TM & 13 & $\mathbf{M}$ & $\begin{array}{l}\text { sulphasalazine } \\
\text { prednisolone }(20 \mathrm{mg} / \text { day })\end{array}$ & Terminal ileum, colon & 62 \\
\hline KB & 13 & $\mathbf{F}$ & nil & Terminal ileum, colon & 75 \\
\hline CB & 14 & $\mathrm{~F}$ & nil & Colon & 83 \\
\hline LP & 14 & $\mathbf{M}$ & nil & Terminal ileum & 66 \\
\hline GH & 15 & $\mathbf{M}$ & $\begin{array}{l}\text { sulphasalazine } \\
\text { prednisolone }(20 \mathrm{mg} / \text { day })\end{array}$ & Colon & 85 \\
\hline $\mathbf{K M}$ & 17 & $\mathbf{M}$ & nil & Terminal ileum, colon & 63 \\
\hline
\end{tabular}

Biopsies from the normal controls were taken from the terminal ileum, ascending, and descending colon. As it has been previously shown that there is no important difference in mast cell density between the two sides of the colon, ${ }^{11}$ biopsies from the colon were assessed together, regardless of the site of origin.

\section{MAST CELL DENSITY}

Biopsies fixed in Carnoy's fluid were sectioned in paraffin at $5 \mu \mathrm{m}$ and stained by the chloroacetate esterase reaction. ${ }^{11}$ The lamina propria mast cells were counted under light microscopy and the area of the section measured by computerised image analysis. ${ }^{12}$

\section{HISTAMINE CONTENT AND HISTAMINE \\ RELEASE}

Biopsies taken from the physiological saline were weighed. They were then washed twice in Tyrode's solution and resuspended in $(0.9 \mathrm{ml})$ Tyrode's solution with bovine serum albumin $(1 \mathrm{mg} / \mathrm{ml})$ (Tyrodes-BSA) for five minutes at $37^{\circ} \mathrm{C}$. Equilibration was helped by gentle mechanical agitation. A further $0.1 \mathrm{ml}$ of Tyrodes-BSA was then added. Histamine release was allowed to proceed for 25 minutes. After centrifugation (two minutes at room temperature at $150 \mathrm{~g}$ ) the supernatant was removed for histamine analysis. The histamine that was released was the spontaneous release.

The biopsy specimen was again washed twice in Tyrode's solution and resuspended in Tyrodes-BSA for five minutes. Heat inactivated rabbit antihuman IgE (Dako, United Kingdom) $(0.1 \mathrm{ml})$ of $1: 100$ was added, and the reaction was allowed to proceed for 25 minutes before centrifugation. The supernatant was taken for histamine analysis. The histamine so released was the release after challenge.
The biopsy was resuspended in $1 \mathrm{ml}$ buffer with perchloric acid (to a final concentration of $2.4 \%$ ) and placed in a boiling water bath for 10 minutes to release the remaining histamine from the biopsy. After centrifugation the supernatant was taken for histamine assay. The histamine released was the residual histamine.

Histamine concentrations were determined spectrofluorometrically using a Technicon autoanalyser II according to the method of Shore et al. ${ }^{13}$

The total histamine content was calculated from the sum of the spontaneous release, release after challenge, and residual histamine. The content was expressed as $\mathrm{ng}$ of histamine $/ \mathrm{mg}$ wet weight of tissue. The percentage spontaneous release was calculated as follows:

$$
\frac{\text { histamine released spontaneously }}{\text { total histamine }} \times 100
$$

The percentage release after anti-IgE challenge was:

$$
\begin{gathered}
\text { histamine released after challenge } \\
\text { histamine released after challenge } \\
+ \text { residual histamine }
\end{gathered}
$$

Significance was assessed by Student's $t$ test, regression analysis, and the Mann-Whitney test.

\section{Results}

The density of lamina propria mast cells was determined in tissue from normal controls and in actively inflamed tissue from children with Crohn's disease and ulcerative colitis (Fig. 1). There was no significant difference between that found in the colon of normal controls and ulcerative colitis. Significantly fewer mast cells, however, were found in inflamed tissue 


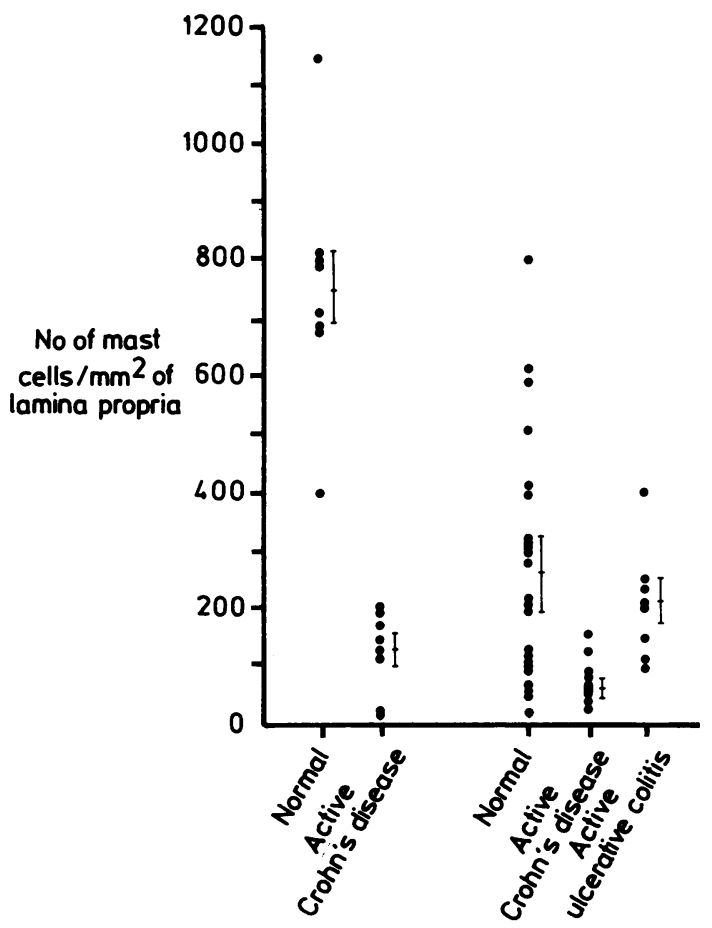

Fig.1 Mast cell density in lamina propria of terminal ileum of normal controls $(n=8)$ and that of Crohn's disease $(n=$ $8)$; and that of colon of normal controls $(n=24)$, of Crohn's disease $(n=9)$, and of ulcerative colitis $(n=8)$. Mean and standard errors.

from children with Crohn's disease in either the terminal ileum $(p<0.001)$ or the colon $(p<0.01)$.

The total histamine content of biopsies from actively inflamed tissue from children with Crohn's disease was also reduced compared with that of normal controls (Fig. 2) both in the terminal ileum ( $p<$ $0.001)$ and in the colon $(p<0.01)$.

Comparing the histamine content of biopsies against mast cell density (Fig. 3) allows the histamine content of individual mast cells to be determined. Assuming that the density of the tissue was $1 \mathrm{mg} / \mathrm{mm}^{3}$, the histamine content was found to be $1.2 \mathrm{pg} / \mathrm{cell}$. Fig. 3 also shows that the regression line passes close to the origin, indicating that there is little histamine outside the mast cells.

Mast cells in biopsies' specimens from normal controls showed little spontaneous histamine release (Fig. 4). When challenged with anti-IgE there was an increased release from nearly all biopsies; the level of this increase, however, varied between $0 \%$ and $24 \%$.

The mast cell histamine release from biopsies of actively inflamed Crohn's disease fell into two groups (Fig. 4). Most showed little spontaneous histamine

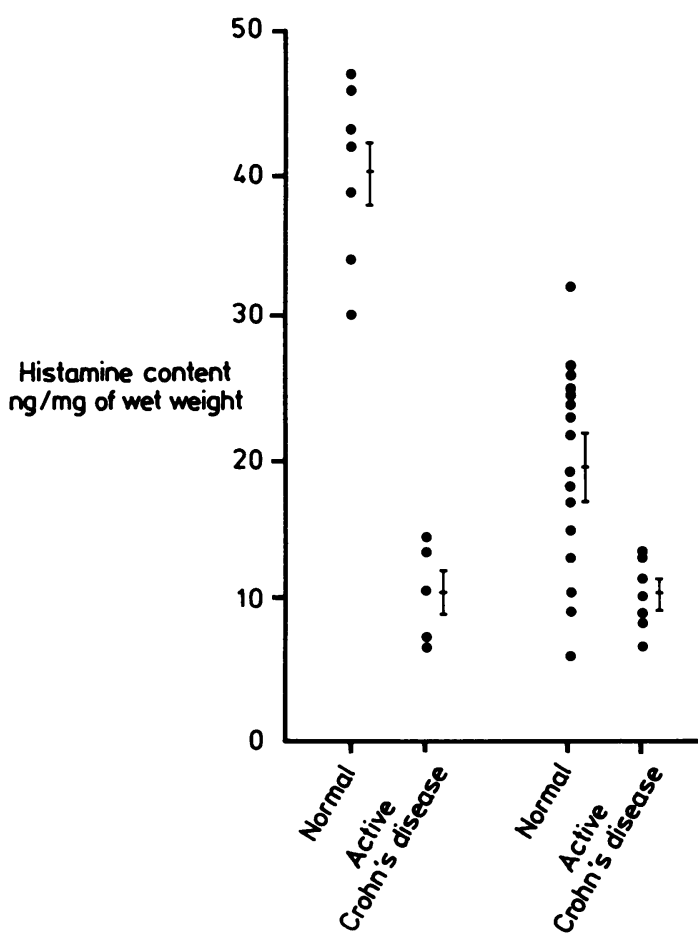

Fig. 2 Histamine content of biopsies from terminal ileum of normal controls $(n=7)$ and of Crohn's disease $(n=5)$; and from colon of normal controls $(n=16)$ and of Crohn's disease $(n=7)$.

release, and the response to anti-IgE, although variable, was not very different from that of normal controls. Three ileal biopsies differed appreciably from this pattern. They showed a large spontaneous histamine release that was unaffected by the addition of anti-IgE.

\section{Discussion}

Mast cell density has been previously claimed as being either increased, ${ }^{14}$ unchanged, ${ }^{315}$ or decreased ${ }^{2}$ in Crohn's disease. In this study, in which great care was taken to biopsy areas that were actively inflamed and to ensure that mucosal mast cells were preserved by using an appropriate fixative, mast cell density was significantly decreased in Crohn's disease. This was true of both the colon and the terminal ileum. This morphological finding was confirmed by measuring the histamine content of adjacent biopsies.

Electron microscopy was routinely performed on biopsies of active tissue from all patients with Crohn's disease. As very little degranulation was found the reduction of mast cell density measured in Crohn's 


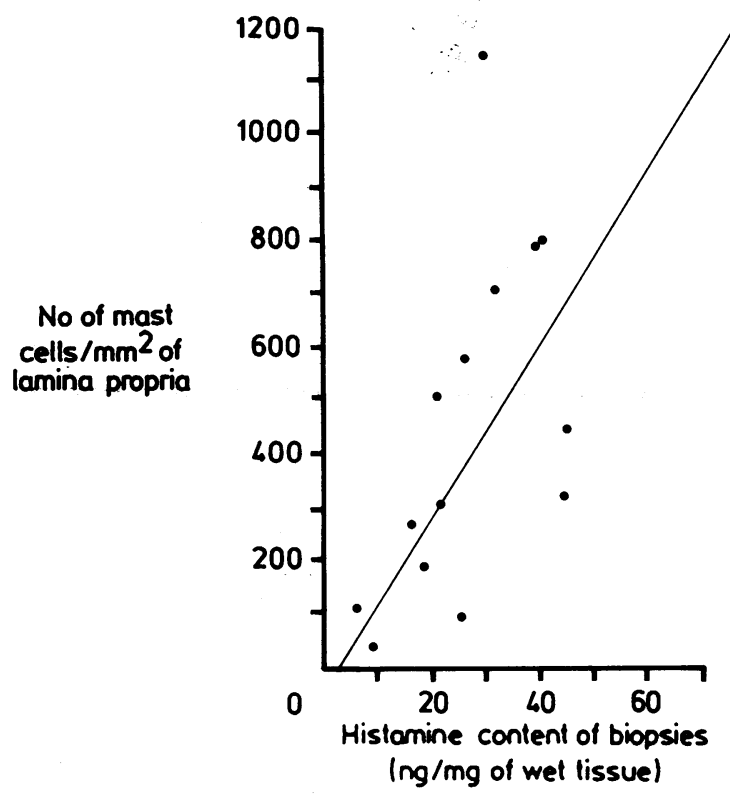

Fig. 3 Histamine content and mast cell density of adjacent biopsies from normal controls. $r^{2}=0 \cdot 67$.

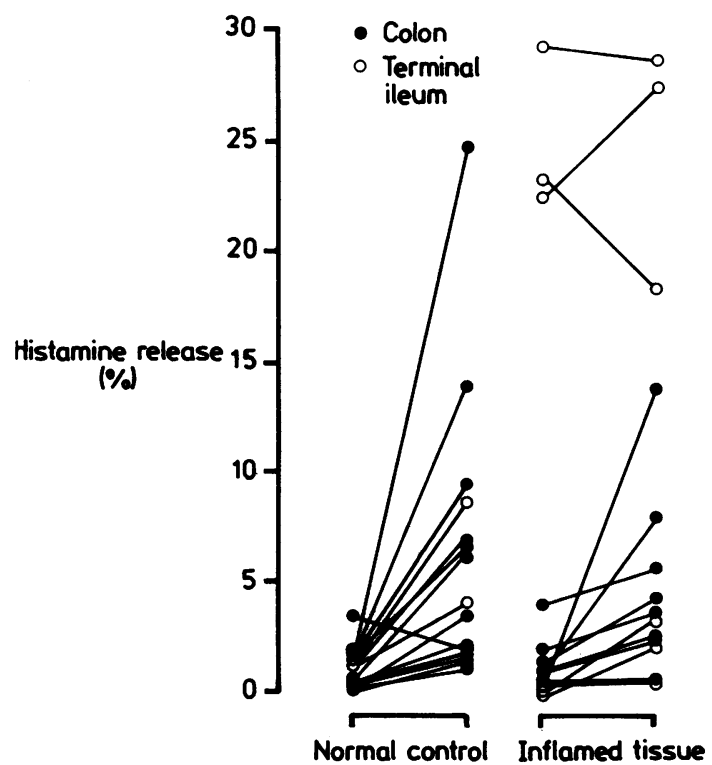

Fig. 4 Histamine release before and after challenge with $1: 100$ anti-IgE in tissue from normal controls $(n=14)$ and in actively diseased tissue $(n=14)$. disease was not an apparent phenomenon that was secondary to the degranulation of mast cells.

The cause of the reduction in mast cells is not easy to explain. Possibly, during the inflammatory process in Crohn's disease cells other than mast cells are preferentially attracted to the area of inflammation. This would lead to a reduction in mast cells, as the biopsied area of bowel is taken up by inflammatory cells and granulation tissue. Mucosal oedema may also reduce the concentration of mast cells per unit area by a dilutional effect.

In normal tissue the amount of histamine in individual mast cells of $1.2 \mathrm{pg}$ per cell agrees closely with that found in lamina propria mast cells in the rat $^{16}$ $[1.3 \mathrm{pg} /$ cell $]$ and in human mast cells from bronchoalveolar lavage ${ }^{7}[1.0 \mathrm{pg} /$ cell $]$. Inaccuracies occur when the histamine contents of biopsies are compared with the density of lamina propria mast cells, as a variable amount of tissue may be biopsied that is not lamina propria. The histamine cell content would be overestimated if muscularis mucosa were taken in the biopsy or underestimated if a lymphoid follicle was included. These inaccuracies should be reduced if several biopsy specimens are examined.

Reactivity to anti-IgE was variable both in normal controls and in actively diseased tissue. This could reflect individual variation in the amounts of $\operatorname{IgE}$ bound to mast cells in different children. This was not related to the atopic state of the child, as assessed by skin prick tests and family history of asthma and hay fever. This is probably because the mast cells responsible for these manifestations are of a different type from those found in the lamina propria of the intestine.

Three patients with Crohn's disease, however, had a high spontaneous release of histamine. The addition of anti-IgE to the bathing solution made little difference to the high degree of release. Normal controls never spontaneously released large amounts of histamine. This suggests that patients with Crohn's disease can have mast cells that degranulate easily but that this phenomenon is not mediated by the reaginic pathway.

In conclusion, there is no convincing evidence that mast cells have an important role in the pathogenesis of Crohn's disease. Their density is reduced rather than increased, as is the histamine content. Although a small proportion of biopsies do exhibit a high spontaneous release, most show no significant difference in release either spontaneously or with anti-IgE from normal controls.

We thank Mrs A Messenger for staining sections for light microscopy and Mr D Lewis and Mr C Stevens for examining specimens under the electron microscope. 


\section{References}

${ }^{1}$ Hiatt RB, Katz L. Mast cells in inflammatory conditions of the gastrointestinal tract. Am J Gastroenterol 1962;37:541-5.

${ }^{2}$ Lloyd G, Green FHY, Fox H, Mani V, Turnberg LA. Mast cells and immunoglobulin $\mathrm{E}$ in inflammatory bowel disease. Gut 1975;16:861-6.

${ }^{3}$ Thompson H, Buchmann P. Mast cell population in rectal biopsies from patients with Crohn's disease. In: Pepys J, Edwards AM, eds. The mast cell, its role in health and disease. London: Pitman Publishing Ltd. 1979:697-701.

${ }^{4}$ Strobel S, Miller HPR, Ferguson A. Human intestinal mast cells: evaluation of fixation and staining techniques. J Clin Pathol 1981;34:851-8.

${ }^{5}$ Dvorak AM, Monahan RA, Osage JE, Dickerson GR. Mast cell degranulation in Crohn's disease. Lancet 1978;1:498.

${ }^{6}$ Church MK, Holgatè ST, Pao GJK. Histamine release from mechanically and enzymatically dispersed human lung mast cells: inhibition by salbutamol and disodium cromoglycate in the rat, rat mast cell and in human lung tissue. Br J Pharmacol 1983;79:347.

${ }^{7}$ Flint KC, Leung KBP, Pearce FL, Hudspith BN, Brostoff J, Johnson N McI. Human mast cells recovered by bronchoalveolar lavage: their morphology, histamine release and the effects of sodium cromoglycate. Clin Sci 1985;68:427-32.

${ }^{8}$ Chong SKF, Bartram CI, Campbell CA, Williams CB, Blackshaw AJ, Walker-Smith JA. Chronic inflammatory bowel disease in childhood. Br:Med J 1982;284:101-3.

${ }^{9}$ Chong SKF, Blackshaw AJ, Boyle S, Williams CB, Walker-Smith
JA. Histological diagnosis of chronic inflammatory bowel disease in childhood. Gut 1985;26:69-74.

${ }^{10}$ Lloyd-Still JD, Green OC. A clinical scoring system for chronic inflammatory bowel disease in children. Dig Dis Sci 1979; 24:620-5.

${ }^{11}$ Sanderson IR, Slavin G, Walker-Smith JA. Mucosal mast cells in the colon and terminal ileum of children J Clin Pathol 1985; 38:771-3.

${ }^{12}$ Maluenda C, Phillips AD, Briddon A, Walker-Smith JA. Quantitative analysis of small intestinal biopsy in cow's milk-sensitive enteropathy. Journal of Paediatric Gastroenterology and Nutrition 1984;3:349-6.

${ }^{13}$ Shore PA, Burkhalter A, Cohn VH. A method for the fluorimetric assay of histamine in tissues. $J$ Pharmacol Exp Ther 1959;127: 182-6.

${ }^{14}$ Dvorak AM, Monahan RA. Crohn's disease-mast cell quantitation using one micron plastic sections for light microscopy. Pathol Annu 1983;18:181-90.

${ }^{15}$ Matsueda K, Rimpila JJ, Ford JE, Levin B, Kraft SC. Tissue mast cells in Crohn's disease and ulcerative colitis. In: Pena AS, Weterman IT, Booth CC, Strober W, eds. Recent advances in Crohn's disease. The Hague: Martinus Nijhoff, 1982:103-9.

${ }^{16}$ Pearce FL, Befus AD, Bienenstock J. Isolation and properties of mast cells from the small bowel lamina propria of the rat. Agents Actions 1982;12:183-5.

Requests for reprints to: Dr IR Sanderson, The Laboratory for Paediatric Gastroenterology, Dominion House, London EClA 7BE, England. 